\title{
EXPLAINING THEORETICAL DISAGREEMENT AND MASSIVE DECISIONAL AGREEMENT: THE JUSTIFICATORY VIEW*
}

\author{
Stefan SCIARAFFA
}

Resumen:

En este artículo esbozo y defiendo una alternativa a la teoría jurídica hartiana, que si bien acepta la teoría hartiana del sistema jurídico, rechaza sin embargo la teoría hartiana del contenido jurídico y aboga por una alternativa no-positivista. Llamo a esta teoria la postura de justificación. Un argumento clave para defender la postura de justificación se erige sobre el problema del desacuerdo teórico que Ronald Dworkin formuló al positivismo hartiano. Además, sostengo que una de las virtudes de esta postura de justificación es que su naturaleza híbrida la protege de las enérgicas críticas que plantea Brian Leiter contra la teoría jurídica de Dworkin. Como observa Leiter, aunque la teoría jurídica de Dworkin sea más consistente que la teoría positivista para explicar el fenómeno marginal de los desacuerdos teóricos entre los oficiales del derecho, la teoría dworkiniana padece mucho más el problema de no poder explicar el contexto de acuerdos masivos en las decisiones que caracterizan a un sistema jurídico. Y esto lo sostengo porque la postura de justificación acepta y se basa en la teoría hartiana del sistema jurídico; por ello es igual de capaz que la teoría jurídica de Hart de explicar este contexto de decisiones que gozan de un acuerdo masivo.

* I would like to thank Imer Flores and Juan Vega Gómez for the opportunity to present the initial version of this paper as a conference presentation at the Universidad Nacional Autónoma de México. I would also like to thank Natalie Stoljar, Wil Waluchow, Mitch Berman, and Fabio Shecaira for their comments. 
STEFAN SCIARAFFA

\title{
Palabras clave:
}

Ronald Dworkin, H. L. A. Hart, debate Hart-Dworkin, desacuerdos en el derecho.

\begin{abstract}
:
In this paper, I outline and defend an alternative to Hartian legal theory that accepts the Hartian theory of a legal system yet rejects the Hartian theory of legal content in favor of a non-positivist alternative. I call this theory the justificatory view. A key argument advanced here in support of the justificatory view relies on the problem of theoretical disagreement that Ronald Dworkin poses for Hartian positivism. Moreover, I argue that a virtue of the justificatory view is that its hybrid nature shields it from the forceful criticism that Brian Leiter marshals against Dworkin's legal theory. As Leiter observes, though Dworkin's legal theory may do better than positivism with respect to explaining the marginal phenomenon of theoretical disagreement among legal officials, Dworkinian legal theory suffers the much greater failing of being unable to explain the background of massive decisional agreement characteristic of legal systems. I argue that because the justificatory view accepts and rests upon the Hartian theory of a legal system, it is no less able than Hartian legal theory to explain this background of massive decisional agreement.
\end{abstract}

Keywords:

Ronald Dworkin, H. L. A. Hart, Hart-Dworkin Debate, Disagreement in Law. 
Summary: I. Theories of Legal Systems and Legal Content. II. Theories of Interpretation and the Positivist's Problem with Theoretical Disagreement. III. Political Morality and Theories of Interpretation. IV. Challenges to the Justificatory View. V. Conclusion.

The phrase "the nature of law" is ambiguous, referring sometimes to the nature of legal systems, sometimes to the nature of a legal system's content (its individual laws), and sometimes expansively to both the nature of a legal system and its content. H. L. A. Hart's theory of law's nature is expansive in this third way. It comprises a theory of a legal system and a theory of legal content. In this paper, I outline and defend an alternative to Hart's theory that accepts his theory of a legal system and rejects his theory of legal content in favor of a non-positivist alternative. I call this theory the justificatory view for reasons that should become clear below.

My argument proceeds in a number of steps. In the first section, I distinguish between Hart's theory of a legal system and his theory of legal content. In this section, I also sketch the possibility of a legal theories that accepts and rests upon Hart's theory of a legal system yet rejects its positivist theory of legal content. The justificatory view I defend here is one such theory. In section two, I explicate the role that a theory of interpretation plays in determining the laws of a legal system, and I describe the problem of theoretical disagreement that Dworkin has posed for the positivist theory of legal content. In part three, I argue that a plausible response to the problem of theoretical disagreement is to abandon the positivist theory of legal content while remaining faithful to the Hartian theory of a legal system. In short, a plausible response is to adopt the justificatory view. Finally, in part four, I consider whether one of Leiter's most forceful objections to Ronald Dworkin's legal theory applies to the justificatory view. Leiter argues that 
though positivist legal theory may have trouble explaining theoretical disagreement amongst legal officials, such disagreement is an infrequent and marginal phenomenon relegated to the hardest cases that arise under the law. By contrast, observes Leiter, Dworkin's theory suffers a much greater explanatory failing, for Dworkin's theory cannot explain a central feature of legal phenomena, the background of massive agreement about law's requirements amongst legal officials. I argue that unlike Dworkinian theory, the justificatory view does not suffer from this problem. This argument brings to the fore an important distinction between Dworkin's theory of law and the justificatory view - namely, the justificatory view relies on the Hartian theory of a legal system, whereas the Dworkinian view lacks a welldeveloped theory of a legal system. As we shall see, it is this difference that shields the justificatory view from Leiter's forceful objection to Dworkinian legal theory.

\section{Theories of Legal Systems AND Legal Content}

Hartian legal theory comprises two parts that should not be conflated. One part is a theory of a legal system. The other is a positivist theory of legal content. In this section, I distinguish between the Hartian theories of a legal system and legal content. I conclude the section by explicating the logical possibility of subscribing to Hart's theory of a legal system while rejecting his theory of legal content.

The main building block of Hart's theory of law is the concept of a social rule. A social rule is a pattern of conduct that a group follows from the internal point of view. ${ }^{1}$ To participate in a pattern of conduct from the internal point of view is to treat that pattern as a standard of behavior that oneself and others ought to follow. Hallmarks of this form of participation in a pattern of conduct is that the members

1 See Hart, H. L. A., The Concept of Law, 2nd. ed., Oxford, Oxford University Press, 1994, pp. 55-58 for Hart's seminal discussion of social rules. 
generally conform to the pattern, they criticize others for deviating from the pattern, and they take deviation from such pattern to be a ground that justifies such criticism.

For Hart, a particular kind of social rule lies at the heart of all legal systems-the rule of recognition. ${ }^{2}$ Hart's conception of the rule of recognition has two distinct aspects that play two distinct theoretical roles in Hart's legal theory. The first aspect is central to Hart's theory of a legal system and the second is central to his theory of legal content.

The first aspect of the rule of recognition is that it is a practice. Like any social rule, the rule of recognition exists as a practice only if a group of person converge sufficiently in their understanding of the relevant standard that each accepts from the internal point of view. To use, Hart's example, a social rule of removing one's hat off in church exists in a group if the members of that group generally and for the most part converge in accepting from the internal point of view the standard that members of the group ought to remove their hats in church. Similarly, on Hart's account, for a rule of recognition to exist, Hart holds that the legal system's officials must converge generally and for the most part in accepting from the internal point of view the same conception of the system's criteria of legal validity.

Hart employs his idea of the rule of recognition qua practice as an element in his account of the existence conditions of a legal system. On his account, a legal system exists only if (1) its officials converge in accepting from the internal point of view more or less the same criteria of legal validity (as well as the system's related rules of change and rules of adjudication), and (2) the system's citizens generally comply with the norms that the system's officials recognize and apply as law. ${ }^{3}$ For present purposes, the first element of Hart's theory of a legal system, particularly the rule of recognition, is the most important for our purposes here.

2 See Hart, op. cit., pp. 94-99 for a discussion of primary and secondary rules.

3 Ibidem, pp. 116-17. 
Whereas a theory of a legal system posits the system's existence conditions, a theory of legal content is an account of what determines the norms that count as valid law in a legal system. One such theory, held by Hart and all positivists, is the social facts thesis. The social facts thesis holds that social facts are the foundational determinants of law in all legal systems. The term "determinants" in this thesis should be taken in a metaphysical sense: laws are composed of social facts, such as the commands of the sovereign or the norms promulgated by particular sources, or they are specified by some social fact, such as the rule of recognition. An implication of this thesis is that moral considerations do not play a foundational role in determining what is and is not law in a legal system.

To explain what it would mean for a moral consideration to play a foundational role in determining the law, it helps to begin with an account of how a moral consideration might play a non-foundational role in determining a legal system's laws. Imagine that the legal officials of a system converge from the internal point of view on a practice of subjecting norms to a moral test before recognizing them as law. For example, they might follow a practice of recognizing only sufficiently just enactments of the legislature as law. In this case, the moral consideration is incorporated as a test of legal validity as a matter of social practice. The moral consideration is a determinant of law because the system's legal officials convergently treat the consideration as such. In this case, the moral consideration is a nonfoundational determinant of the legal system's laws.

By contrast, a moral consideration would play a foundational role in determining the law if it played a role in determining legal validity irrespective of whether the relevant legal officials converge in accepting that the moral consideration plays such a role. For example, if minimal justice were a condition of a norm's legal validity irrespective of whether the legal system's officials convergently 
treated such a consideration as such a determinant, then it would be a foundational determinant of law.

Hart subscribes to the social fact thesis. Hence, he holds that the foundational determinants of laws are social facts. Specifically, Hart holds that the standard that a system's officials converge in accepting determines what count as law in the system. Here, we have a second aspect of the rule of recognition. As mentioned above, the first aspect is the rule of recognition qua the convergent practice among a legal system's officials of treating more or less the same complex standard as the system's criteria of legal validity. The second aspect of the rule is the rule of recognition qua the abstract object that the system's officials converge in accepting. According to Hart's legal theory, the particular abstract object that is the object of official convergence among a legal system's officials is the rule that determines what counts as valid law in the system.

It is important to recognize that the Hartian theories of a legal system and legal content are conceptually distinct. Moreover, one does not directly imply the other. It is one thing to say that a legal system exists only if its officials converge sufficiently in the criteria of legal validity that they accept, and it is another to say that the laws of a legal system are all and only those norms that are specified by the criteria of validity that the officials converge upon. To illustrate this conceptual distinction, consider a case in which two groups of legal official fully converge in their understanding of every detail of their system's criteria of legal validity save for one difference. One group holds that legislative enactments are law, including entrenched provisions of such enactments that impose supermajority requirements on future legislatures who might seek to amend or strike the entrenched enactment, whereas a second group holds that legislative enactment generally are law but that any provision putatively entrenching such a law is not legally 
valid. ${ }^{4}$ Thus, these two groups disagree about the legal validity of provisions that purport to entrench a law. What should we say about the legal status of such provisions in this legal system? Are they valid law or not?

The Hartian answer to this question is not obvious. As we have seen, Hart's view is that what counts as law in a legal system is determined by ther criteria of legal validity that the system's officials converge in accepting. However, in this case, there is no convergence with respect to the relevant elements of the system's rule of recognition. Perhaps, in this case, the Hartian must say that it is indeterminate whether entrenching provisions are legally valid. However, this is not the only possible approach. To see this, consider the perspectives of the officials described in the example.

As described, the officials themselves seem to hold particular views about the system's criteria of validity that differ from the Hartian theorist's view. Contra the Hartian view, these officials do not hold that their system's criteria of validity are those and only those that the system's officials converge in accepting. Rather, one set of officials hold that the system's criteria of validity recognize entrenching provisions as valid law and the other set holds that such provisions are not valid law. And these officials persevere in this disagreement about the system's criteria of legal validity despite the fact that each set of officials knows that there is no convergence among the system's officials with respect to this element of the system's rule of recognition. For our purposes here, the important point to draw from this discussion is that the officials in this example could coherently subscribe to Hart's theory of a legal system, and hence accept that a legal system does not exist absent sufficient convergence among the system's officials with respect to the system's rule of recognition, while at the same time continuing to insist that the criteria of legal validity that determine what is law in their system are the criteria that she

4 This is an example that Hart draws from the legal history of South Africa. Hart, op. cit., pp. 122-23. 
accepts rather than the criteria that the group as a whole converges in accepting. In sum, a legal official might coherently accept the Hartian theory of a legal system, yet reject the Hartian theory of legal content.

The justificatory view similarly subscribes to Hart's theory of a legal system, yet rejects its theory of legal content in favor of an alternative. This view holds that the laws of a legal system are those norms picked out by criteria of legal validity understood through the lens of the underlying political and moral values that justify the officials' participation in the system's rule of recognition qua general practice. For example, this theory holds that to determine in the example above whether the entrenching provisions of a law are valid law, one must first consider the moral and political values that justify the legal officials' generally convergent practice of treating certain classes of norms, e.g., those enacted by a democratic legislature, as valid law. If these values support treating such entrenching provisions as valid law, then such provisions are valid law. If they support not treating entrenching provision as law, then such provisions are not law.

In sum, in this section I have argued for the conceptual possibility of a theory that accepts the Hartian theory of a legal system, yet rejects the Hartian theory of legal content in favor of a justificatory approach that relies upon the Hartian theory of a legal system. In the following, I adduce a number of considerations that speak to the relative merit of the justificatory approach vis-à-vis Hartian and Dworkinian legal theory.

\section{Theories of Interpretation And the Positivist’s Problem WITH THEORETICAL DisAgREEMENT}

Dworkin holds that the fact of theoretical disagreement among a legal system's officials poses a problem for Hartian 
positivism. ${ }^{5}$ Theoretical disagreement is disagreement among a system's officials about their system's criteria of legal validity. The specific disagreement that Dworkin and others have raised is with respect to theories of interpretation. Thus, a necessary preliminary to discussing the problem that theoretical disagreement poses for positivism, we must say a few more words about theories of interpretation and their relationship to source-identifying criteria of legal validity. ${ }^{6}$

Source-identifying criteria are not a sufficient basis for determining the laws of a legal system, for such criteria must combine with a theory of interpretation in order to specify the meaning of such system's laws. To see this, consider three alternative interpretive approaches to the meaning of the provisions of a written constitution: intention-based originalism, plain meaning originalism, and the living tree approach. For the purposes of developing our i1lustrative example, let us consider each approach as it applies to section 12 of the Canadian Charter of Rights and Freedoms.

Section 12 holds that "[e]veryone has the right not to be subjected to any cruel and unusual treatment or punishment." Our present question queries how we go about determining the content of this provision. Intention-based

5 See Dworkin, Ronald, Law's Empire, Cambridge, Mass., Harvard University Press, 1988, and Shapiro, Scott J., "The 'Hart-Dworkin' Debate: A Short Guide for the Perplexed", in Ripstein, Arthur (ed.), Ronald Dworkin, New York and Cambridge, Cambridge University Press, 2007.

6 One might question whether the theorist should classify a theory of interpretation as part of the rule of recognition or as a law-determining consideration that complements the rule of recognition. See Berman, Mitch, "Constitutional Theory and the Rule of Recognition", in Adler, Matthew \& Himma, Kenneth (eds.), The Rule of Recognition and the U.S. Constitution, New York, Oxford University Press, 2009, p. 273, n. 13 for a brief discussion of this issue. I do not see that anything important rides on this bit of conceptual bookkeeping. The crucial claim here and in Berman's piece is that a theory of interpretation is a necessary law-determining consideration that any complete theory of law must accommodate. I am thankful to Mitch Berman for urging me to clarify this issue. 
originalism is one possible answer to this question. On this account, the meaning of the Charter is the authorial intention behind the writing of the Charter. The meaning of the provision forbidding cruel and unusual punishment just is whatever the authors of this provision intended when they passed it.

Convention-based (plain meaning) originalism is unconcerned with authors' intentions. Rather, on this view, the meaning of a provision is determined by the linguistic practices in force at the time of its enactment. Intention-based meaning and convention-based meaning can diverge. For example, the authors of the cruel and unusual punishment provision could have enacted the provision with the specific intention of prohibiting a very specific and short list of punishments. The intention-based meaning, then, would be a prohibition against this set of punishments. By contrast, the convention-based meaning of the prohibition of cruel and unusual punishment is determined by the conventional understanding of the meaning of the provision's words at the time of the provision's enactment. We might imagine that understood in terms of this conventional-meaning, the provision forbids any punishment that is cruel and unusual. Thus, it forbids a general class of punishments, of which there are many different instances, rather than the short list of punishments that we are imagining was the intention of the provision's authors.

Whereas the meaning of a text under the plain-meaning and intention-based approaches is fixed, the living tree approach allows for the meaning of a text to change over time along with the society's moral understanding. On Wil Waluchow's account of this approach, the meaning of a charter is to be found in the community's constitutional morality $(\mathrm{CCM}){ }^{7} \mathrm{CCM}$ is implicit in the community's public political culture; it is, as Waluchow says citing Dworkin, "the morality presupposed by the laws and institutions of

7 Waluchow, Wil, A Common Law Theory of Judicial Review, Cambridge, UK, Cambridge University Press, 2007.

175 
the community". 8 A key constituent of this morality is the Charter, but there are other constituents as well, including legal decisions, laws on the books, and perhaps even general political practices and sensibilities within society. On Waluchow's construction of the living tree approach, the first step of the judge interpreting the Charter is to identify the community's constitutional morality. Thus, the judge does not apply her own moral and political views when applying the abstract terms of the charter; rather, she seeks to discern and apply the community's views implicit in the community's practices and institutions. Hence, a judge applying a provision of the Charter, say the cruel and unusual punishment clause, specifies the meaning of the clause in terms of the community's understanding of what cruel and unusual punishment is and why it is important to prohibit it.

It should be clear from the foregoing discussion that the legal content of a particular text may differ depending on which interpretive approach one takes. The intention of the charter's authors when expressing the term "cruel and unusual punishment" may differ from the phrase's plain meaning. In turn, the plain meaning and intention-based meaning of the phrase may differ yet again from the meaning based on the community's constitutional morality. This variety of interpretive approaches and corresponding variety of possible legal contents of a charter has an important implication. Namely, the source-identifying criteria of legal validity that recognize certain classes of norms as valid law, do not fully determine the legal content, the laws, of a legal system. These criteria must be supplemented with a theory of interpretation to determine fully a legal system's content. In sum, the laws of an intention-based legal system would be very different from the laws of a plain-meaning-based legal system, which in turn would be very different from a CCM-based legal system, even if the relevant source-identifying criteria of legal validity of each system were identical.

8 Ibidem, p. 227. 
The fact that a theory of interpretation plays a key role in determining the laws of a legal system invites a further question. What fixes a legal system's theory of interpretation? What determines whether a legal system's officials should look to plain meaning, intention, CCM, or some other theory of interpretation to determine the legal content, the laws, of the system? I will consider two answers to this question: the Hartian legal positivist answer and the justificatory view.

The positivistic answer to this question is social facts. On this view, the practice of legal officials fixes the system's theory of interpretation. Moreover, this view holds that the legal system's rule of recognition and theory of interpretation that the legal officials convergently apply combine to fix the laws of the system. Note that on this account, the convergently accepted theory of interpretation may vary with context. For example, legal officials might convergently accept an intention-based approach with respect to certain kinds of statutory law, yet converge upon a living tree approach in the area of constitutional law. Moreover, this contextual variation might be extremely fine-grained. For example, within constitutional law, the legal officials might convergently take an intention-based approach in the context of structural constitutional issues (those allocating powers to various governmental organs), yet take one of the other approaches to rights-based issues.

The problematic implication of the positivist's approach to fixing a legal system's theory of interpretation is that it holds the determinacy of the law hostage to the existence of a settled interpretive practice. On this view, insofar as there is no convergent interpretive practice, there is no way to fix the theory of interpretation that couples with the legal system's rule of recognition to determine fully the law. However, interpretive approaches often remain unsettled. ${ }^{2}$ For

9 Andrea Dolcetti and Giovanni Ratti usefully discuss the distinction between source-identifying criteria of legal validity and theories of interpretation in "Legal Disagreements and the Dual Nature of Law", in 
example, intentionalist originalism, plain-meaning originalism, and an analog of the living tree approach each have a formidable contingent of defenders in American courts and legal scholars. In such a context, the positivist must conclude that the relevant body of law, in this case constitutional law, is indeterminate in those cases where it is unsettled what interpretive approach applies and in which the different interpretive approaches lead to different results. Perhaps, this is the right thing to say about American law. However, counting against the positivist answer is that this characterization of constitutional law does not fit with the professed understanding of the judges who decide these cases. To see this consider the rhetorical posture of the dissents and court opinions in two cases that came before the U.S. Supreme Court: Marsh $v$ Chambers and Griswold $v$ Connecticut. 10

The question before the court in Marsh was whether the state of Nebraska's practice of opening legislative session with prayer violates the Establishment Clause of the American Constitution's First Amendment. This clause prohibits the establishment of a state religion. Writing for the Court, Burger employed the intention-based interpretive approach to determine the meaning of this clause. I quote at some length:

In this context, historical evidence sheds light not only on what the draftsmen intended the Establishment Clause to mean, but also on how they thought that Clause applied to the practice authorized by the First Congress - their actions

Waluchow, W. \& Sciaraffa, S. (eds.), Philosophical Foundations of the Nature of Law, Oxford, Oxford University Press (forthcoming). They also argue that disagreement among legal officials about theories of interpretation is characteristic of many legal systems.

10 Marsh v Chambers, 463 U.S. 783 (1983) and Griswold v Connecticut, 381 U.S. 479 (1965). See Mitch Berman (forthcoming), "Constitutional Construction and Constitutional Decision-Rules", Constitutional Commentary 27, pp. 110-12 for a similarly illustrative example of different approaches to interpreting the meaning of the law.

178 
reveal their intent. An Act "passed by the first Congress assembled under the Constitution, many of whose members had taken part in framing that instrument,... is contemporaneous and weighty evidence of its true meaning".

It can hardly be thought that in the same week Members of the First Congress voted to appoint and to pay a chaplain for each House and also voted to approve the draft of the First Amendment for submission to the states, they intended the Establishment Clause of the Amendment to forbid what they had just declared acceptable. In applying the First Amendment to the states through the Fourteenth Amendment, it would be incongruous to interpret that Clause as imposing more stringent First Amendment limits on the states than the draftsmen imposed on the Federal Government. ${ }^{11}$

Here, the Court found that the authors of the American Constitution did not intend for the Establishment Clause to have the effect of prohibiting governmental bodies from opening their sessions in prayer. According to the Court, such intent determines the meaning of the Establishment Clause. Thus, the Court held that the Establishment Clause does not prohibit such opening prayers. For present purposes, it is important to note the rhetorical stance the Court takes. Burger takes the evidence of intent as indicative of the "true meaning" of the Establishment Clause. Despite the fact that the dissent in this case rejected Burger's interpretive approach, there is no hint here that Burger takes the law to be indeterminate in this case in need of judicial construction; rather, he presents himself as discerning its meaning. This rhetorical stance is not limited to originalists. For example, consider Griswold $v$ Connecticut.

In Griswold, the United States Supreme Court considered the constitutionality of a state law forbidding the use of contraceptives. The Court struck down the law. The Court held that despite the fact that the Constitution nowhere explicitly mentions privacy rights that it nonetheless protects

11 Marsh, 463 U.S. at 790. 
them. In a concurring opinion, Justice Goldberg justifies his decision in terms of a living tree approach to constitutional interpretation:

[A] judicial construction that this fundamental right [to privacy] is not protected by the Constitution because it is not mentioned in explicit terms by one of the first eight amendments or elsewhere in the Constitution would violate the Ninth Amendment, which specifically states that " $t]$ he enumeration in the Constitution, of certain rights, shall not be construed to deny or disparage others retained by the people..."

In determining which rights are fundamental, judges are not left at large to decide cases in light of their personal and private notions. Rather, they must look to the "traditions and [collective] conscience of our people" to determine whether a principle is "so rooted [there]... as to be ranked as fundamental". The inquiry is whether a right involved "is of such a character that it cannot be denied without violating those 'fundamental principles of liberty and justice which lie at the base of all our civil and political institutions'... ${ }^{12}$

Like the originalist opinion above, this living-tree oriented opinion assumes the rhetorical stance of discerning rather than constructing Constitutional guarantees. As with March, this concurring opinion nowhere suggests that the relevant law is indeterminate and in need of judicial construction. Moreover, in this case, the concurring opinion assumes this rhetorical stance in the face of a vigorous dissent anchored in an originalist theory of interpretation.

I submit that, as exemplified in Marsh and Griswold, American courts typically assume a rhetorical stance of discerning rather than constructing the law in those cases where they apply an interpretive approach that has not achieved widespread acceptance. ${ }^{13}$ If I am correct in this

12 Griswold, 381 U.S. at 493.

13 Canadian judges seem to have converged upon one constitutional interpretive approach, the living tree approach. Note three points about 
assertion, then the positivist's view that the law is indeterminate insofar as the officials of a legal system have not converged upon one interpretive approach is at odds with an important thread of judicial practice. A plausible positivistic response in this context would be suspicion of the court's self-presentation. Understandably, a court may seek to preserve its legitimacy by presenting itself as discerning the law's meaning when it is actually making or constructing it. Or, courts may simply be confused about what they are doing in these cases. ${ }^{14}$ However, we should only reach such conclusions if there is no other equally plausible characterization of legal practice that fits with the court's self-presentation and seeming self-understanding.

\section{Political Morality and Theories of Interpretation}

Looking to context and underlying considerations of political morality is an alternative to the positivist's strategy of looking to convergent practice for the proper theory of interpretation to employ in determining the law. To see this, consider the practiced rule of recognition of a constitutional democracy. In such a legal system, the system's officials generally converge in treating a particular written constitution and enactments of a democratically enacted legislature

this. First, judges' understanding of how this approach works may significantly differ and, thus, threaten an indeterminacy in the law similar to the one generated by a multiplicity of theories of interpretation. Second, Canadian judicial review is a relatively young institution. Controversy may yet arise. Third, we can make a point about the Canadian case that is similar to the point made above about the American case. When the living tree approach was first applied to the Canadian Charter, there was no practice of applying that approach to the Charter. Nonetheless, in these early Charter cases, the Court strikes the rhetorical pose of discerning rather than constructing or making the law. See, e.g., R v. Big M Drug Mart. [1985] 1 SCR 295 at 344.

14 See Brian Leiter's discussion of these possibilities under the head of the Disingenuity and Error Theses in "Explaining Theoretical Disagreement”, University of Chicago Law Review 76, pp. 1224-25. 
as sources of law. Moreover, as a matter of common practice, they subordinate the legislative enactments to the constitution.

A reflective participant in the constitutional-democratic rule of recognition queries the justification of treating only the constitutional enactments of the democratic legislature as law. According to the justificatory view, the appropriate interpretive approach to take to constitutional provisions is determined by answering this reflective participant's question. For illustrative purposes, let us consider again intention-based originalism and the living tree approach, respectively.

Richard Kay defends intention-based originalism. The key premise of this defense holds that "effective liberty requires assurance as to its duration and extent". ${ }^{15}$ On this view, planning and pursuing a meaningful life plan is fatally undermined unless the subject can predict the ways in which the state might intrude upon and constrain the course of one's life. Thus, effective liberty requires the existence of robust and certain limits on the power of the state. Kay argues that the certainty necessary for effective liberty is best secured when courts interpret the provisions of the Constitution in terms of their originally intended meaning. Kay's idea is that if courts were to interpret the Constitution on the basis of original intent, then subjects would know with great certainty the extent of state power that the Constitution permits. This stands in contrast with other approaches, such as living tree approaches, which rely on controversial and less easily predicted judicial reasoning to determine the Constitution's meaning.

In sum, Kay provides a theory that justifies the constitutional-democratic rule of recognition and its complementary theory of interpretation. A clause that recognizes democratically enacted laws subject to the constitution is justified

15 Kay, Richard, "American Constitutionalism", in Alexander, Larry (ed.), Constitutionalism, New York, Cambridge University Press, 1998, p. 27 . 
because such an arrangement enables a state to perform the necessary tasks of governance with clear and predictable limits necessary for citizens' effective realization of their liberties. Given this underlying value of the constitutional-democratic structure of the rule of recognition, the appropriate interpretive method is the one that best secures this value. On Kay's view, intention-based originalism best protects the citizenry's effective liberty.

As we have seen, Wil Waluchow defends and develops at length a version of the living tree interpretive approach. On his view, judicial review of democratic governance is justified by the underlying value of democracy. Waluchow conceives of this value in terms of self-rule by the democratic community. He asserts that "[o]ne might reasonably claim that what determines whether a system is democratic is whether, and to what extent, the interests, wishes, and convictions of citizens are reflected in whatever decisionmaking procedure is adopted...". ${ }^{16}$ Moreover, Waluchow adds that there are a set of core or true commitments common to all, or at least the bulk, of the citizens of a democracy. To satisfy the underlying value of democracy, the state must govern in a way that holds fast to the core commitments of the democratic community. Unfortunately, a state guided by majority-rule does not always do this. The task of judicial review, then, is to police the democratic assembly to ensure that it does not stray from the democracy's core commitments. Thus, courts face a dual task. They must identify the core commitments of the democratic community, the community constitutional morality, and they must strike down laws that are not consistent with these commitments.

In sum, Waluchow, like Kay, takes the underlying value of the constitutional democratic rule of recognition to dictate the appropriate interpretive approach to the state's constitution. However, Kay's and Waluchow's respective conceptions of this underlying value differs, which, in turn,

16 Waluchow, W., A Common Law Theory, p. 108. 
leads to a difference in interpretive approach to the meaning of the Constitution's provisions.

I submit that, contra the Hartian theory of legal content, fixing the proper interpretive approach to the constitution does not turn on the convergence of an interpretive practice amongst legal officials. Rather, the proper interpretive approach is determined by political and moral considerations. Above, we saw that Kay and Waluchow supply different views of what the important political and moral considerations are in the context of a constitutional-democratic rule of recognition. According to the justificatory view, the proper interpretive approach in the constitutional-democratic context is the one that is implied by the best or correct account (whether it be Kay's, Waluchow's, or some other view yet to be considered) of the underlying value of the constitutional-democratic rule of recognition. A virtue of the justificatory view is that it, unlike the Hartian theory of legal content, is consistent with judge's practice of unhesitatingly and determinately stating what the law is in cases where there is manifest disagreement among legal officials about the theory of interpretation to apply.

\section{Challenges to the Justificatory View}

In one key respect, the present defense of the justificatory view mirrors Ronald Dworkin's defense of law as integrity, his theory of law. Namely, a key pillar supporting both Dworkin's and the justificatory view is that it better responds to the problem of theoretical disagreement than does a positivist view. A key difference between Dworkin's legal theory and the justificatory view is that the justificatory view is better able to withstand a powerful line of criticism that Brian Leiter marshals against Dworkinian legal theory.

Leiter rightly observes that putative cases of theoretical disagreement are, for the most part, limited to appellate cases and thus afflict only a tiny fraction of the legal judg- 
ments and decisions that legal officials make. ${ }^{17}$ Leiter challenges Dworkin to explain why the theorist of law should construct a theory around such a marginal feature of the law. More pointedly, he argues that the problem with Dworkin's view, and by extension, the justificatory view, is that the theoretical cost of these theories explanation of theoretical disagreement is too great, for though such theories may make sense of the marginal phenomenon theoretical disagreement, they fail to explain or make sense of the massive agreement that we find in legal systems.

But when the most striking feature about legal systems is the existence of massive agreement about what the law is, then any satisfactory theory has to do a good job making sense of that to be credible. Not only does positivism have such an explanation, noted earlier, but Dworkin's theory makes the massive agreement about law, at best, surprising, since for Dworkin, the positive history of institutional actions and decisions (e.g., by courts and legislatures) does not exhaust a community's laws. Rather, on Dworkin's view, the law includes the moral principles that figure in the best explanation and justification of that history, as well as whatever concrete decisions follow from those principles. Thus, the law, on Dworkin's view, is in principle esoteric, since much, indeed all, of the "law" in a community might be unknown, indeed never known, by members of that community insofar as they fail to appreciate the justificatory moral principle $\mathrm{s}$ and their consequences. If this were the true nature of law, the existence of massive agreement might seem puzzling indeed. ${ }^{18}$

Leiter's thought here seems to be that the positivist can explain a central feature of legal practice that Dworkin's theory cannot. Namely, positivist legal theory can explain legal officials' massive decisional agreement, i.e. agreement about the proper disposition of particular cases. However, it

17 Leiter, B., op. cit., pp. 1226-27.

18 Idem. 
is not clear from Leiter's comments exactly how positivism better explains or better makes sense of such agreement. As we have seen, positivism encompasses a theory of legal content and a theory of a legal system. Leiter does not specify which element of positivist legal theory supplies the explanation of massive agreement.

Recall that the positivist theory of legal content that we are considering holds that the laws of a legal system are those norms that are picked out by the theory of interpretation and the source-identifying criteria of legal validity that the system's officials converge in accepting. This theory does not explain massive decisional agreement among legal system's officials. Rather, it holds that insofar as there is requisite agreement about the rule of recognition's theory of interpretation and source-identifying norms, there is determinate legal content in the system. Thus, the positivist theory of legal content does not provide the explanation of massive agreement that Dworkin's view lacks.

Perhaps, then, Leiter's criticism should not be understood as criticism of the relative merit of Dworkinian theory of legal content but rather a criticism of the relative merit of the Dworkinian theory of a legal system. As we have seen, the positivist theory of a legal system holds that a legal system exists only insofar as there is sufficient agreement among its officials about the system's rule of recognition. Hart's idea seems to be that absent such widespread agreement, there would be no legal system. Rather, there would be a cacophony of conflicting and unordered rules and requirements, and, as Leiter might observe, there subsequently would be no massive decisional agreement characteristic of a system of rules. Thus, Hart provides a kind of constitutive explanation of a legal system that explains massive decisional agreement. A legal system is set of practiced rules ordered in such a way that there is massive decisional agreement about its requirements. By contrast, Dworkin offers no such constitutive explanation of a legal system. More pointedly, Dworkin does not have a well-de- 
veloped theory of a legal system at all. Rather, he describes the relevant phenomena broadly as a legal practice constituted by some set of political decisions and observed norms. ${ }^{19}$ Thus, Dworkin's theory, unlike Hart's theory of law, provides no theory of a legal system, and hence leaves unexplained the massive decisional convergence characteristic of legal systems.

By contrast, the justificatory theory I offer here is not similarly deficient, for it accepts and rests upon the Hartian theory of a legal system. The justificatory view agrees that a legal system exists only if there is sufficient convergence among its officials with respect to the rule of recognition. However, the justificatory view emphasizes that this convergence need not be full convergence. Rather, it need only be sufficient to sustain the massive decisional convergence characteristic of a system of rules rather than a cacophony of conflicting directives. This is compatible with a great deal of disagreement about the proper theory of interpretation to apply to legal sources, and even some disagreement at the margins with respect to the source-identifying elements of

19 Dworkin's characteristic resistance to theorizing about law's existence conditions is exemplified in this passage from Law's Empire:

"Each lawyer has joined the practice of law with the furniture in place and with a shared understanding that these institutions together form our legal system. It would be a mistake-another lingering infection from the semantic sting - to think that we identify these institutions through some shared and intellectually satisfying definition of what a legal system necessarily is and what institutions necessarily make it up. Our culture presents us with legal institutions and with the idea that they form a system. The question which features they have, in virtue of which they combine as a distinctively legal system, is part of the interpretive problem. It is part of the controversial and uncertain process of assigning meaning to what we find, not a given of the preinterpretive structure".

Dworkin R., Law's Empire, Cambridge, Mass., Harvard University Press, 1986, p. 91. In short, the justificatory view is sympathetic to the idea that determining the fine-grained detail of a system's criteria of legal validity is a matter of interpretation, but rejects Dworkin's thought that theorizing about the basic structure of a legal system is an interpretive rather than an explanatory-descriptive project. 
the rule of recognition, so long as the decisions reached from these somewhat varying perspectives about the system's rule of recognition generally overlap. ${ }^{20}$ Thus, the justificatory view supplies a constitutive explanation of a legal system, and hence, massive decisional convergence. In sum, because the justificatory view clearly distinguishes between a theory of a legal system and a theory of legal content and because it accommodates the fact of massive convergence it in its theory of a legal system in the same way that Hart's legal theory does, it avoids Leiter's charge of failing to explain the massive convergence characteristic of legal systems as well as Hart's positivism.

\section{Conclusion}

The justificatory view joins Hart in holding that a legal system exists if there is sufficient convergence among its legal officials with regard to the system's secondary rules, which includes the system's criteria of legal validity. However, the justificatory view emphasizes that convergence sufficient for a legal system's existence is not full convergence. Sufficient convergence is consistent with extensive disagreement about theories of interpretation and, at the margins, disagreement about the sources of law. Moreover, the justificatory view rejects the Hartian theory of legal content in favor of a theory that casts considerations of political morality as foundational determinants of law.

The preliminary defence and sketch of the justificatory view offered here has accomplished a number of objectives. First, it has emphasized an important and often conflated distinction between theories of legal content and legal systems. It has outlined the justificatory view, and argued that this legal theory can better explain theoretical disagreement than the legal positivist view. Moreover, it has explained

20 For further discussion of the commonplace occurrence of massive decisional agreement despite disagreement about theories of interpretation, see Dolcetti and Ratti (forthcoming), op. cit. 
how that this non-positivist theory of law differs from Dworkin's in that it accepts and is predicated upon a Hartian theory of a legal system. And finally, it argues that because the justificatory view accepts and rests upon the Hartian theory of a legal system, it is not vulnerable to a forceful line of attack against Dworkin's theory of law. Unlike Dworkin's theory, the justificatory view is no less able than Hartian legal theory to explain massive agreement characteristic of legal systems, for the justificatory view accepts the Hartian theory of a legal system that explains such agreement. 
DR (C) 2012, Universidad Nacional Autónoma de México,

Instituto de Investigaciones Jurídicas 